ORNL/TM-12723

\title{
ENERGY EFFICIENCY IN MILITARY HOUSING: MONITORING TO SUPPORT REVITALIZATION GUIDEBOOK
}

\author{
William P. Levins \\ Mark P. Ternes
}

OAK RIDGE NATIONAL LABORATORY

\section{MARTIN MARIETRA}

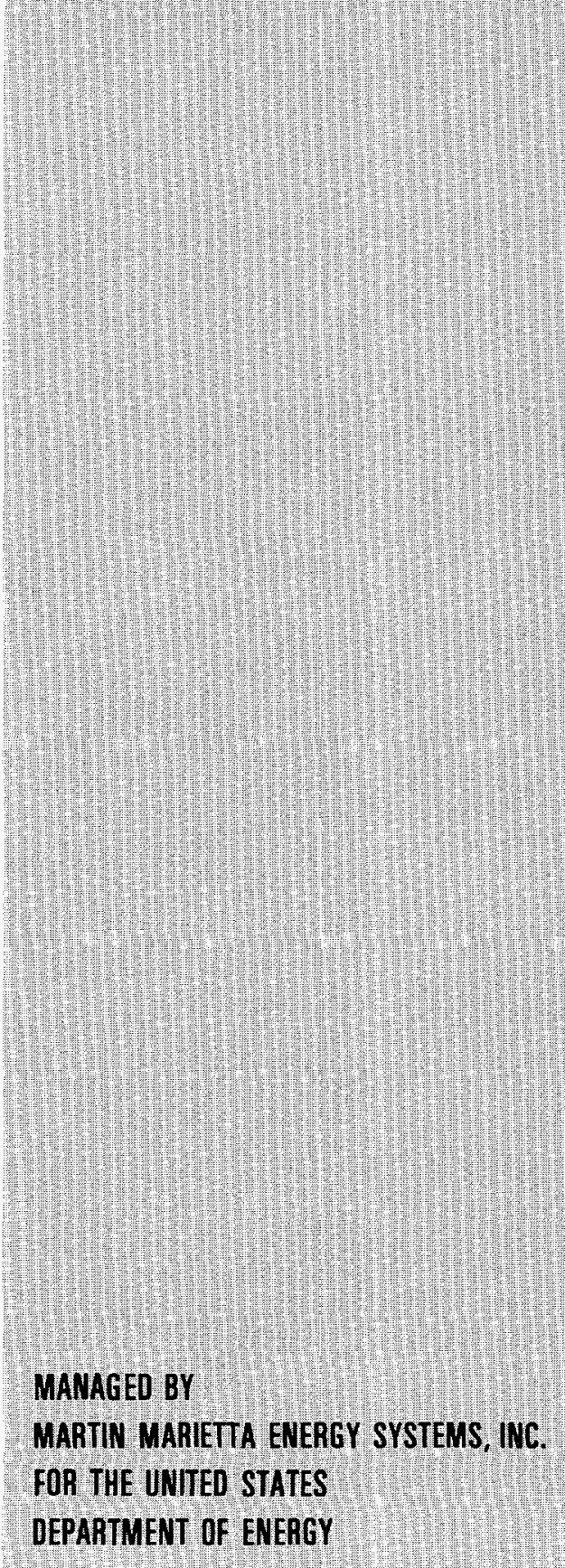

\section{MANAGED B}

AN WAMETA ETERGY STSTEMS, NG. DEPARTMENT OF ENERGY
This report was prepared as an account of work sponsored by an agency of the United States Government. Neither the United States Government nor any agency thereof, nor any of their employees, makes any warranty, express or implied, or assumes any legal liability or responsibility for the accuracy, completeness, or usefulness of any information, apparatus, product, or process disclosed, or represents that its use would not infringe privately owned rights. Reference herein to any specific commercial product, process, or service by trade name, trademark, manufacturer, or otherwise does not necessarily constitute or imply its endorsement, recommendation, or favoring by the United States Government or any agency thereof. The views and opinions of authors expressed herein do not necessarily state or reflect those of the United States Government or any agency thereof. 
This report has been reproduced directly from the best available copy.

Available to DOE and DOE contractors from the Office of Scientific and Technical Information, P.O. Box 62, Oak Ridge, TN 37831; prices available from (615) 576-8401, FTS 626-8401.

Avaliable to the public from the National Technical Information Service, U.S. Department of Commerce, 5285 Port Royal Rd., Springfield, VA 22161.

This report was prepared as an account of work sponsored by an agency of the United States Government. Neither the United States Government nor any agency thereof, nor any of their employees, makes any warranty, express or implied, or assumes any legal liability or responsibility for the accuracy, completeness, or usefulness of any information, apparatus, product, or process disclosed, or represents that its use would not infringe privately owned rights. Reference herein to any specific commercial product, process, or service by trade name, trademark, manufacturer, or otherwise, does not necessarily constitute or imply its endorsement, recommendation, or favoring by the United States Government or any agency thereof. The views and opinions of authors expressed herein do not necessarily state or reflect those of the United States Government or any agency thereof.






\section{DISCLAIMER}

Pórtions of this document may be illegible in electronic image products. Images are produced from the best available original document. 
ORNL/TM-12723

\title{
ENERGY DIVISION \\ ENERGY EFFICIENCY IN MILITARY FAMILY HOUSING: MONITORING TO SUPPORT REVITALIZATION GUIDEBOOK
}

\author{
William P. Levins \\ Mark P. Ternes \\ Oak Ridge National Laboratory \\ Existing Buildings Research Program \\ Energy Division
}

November 1994

Prepared for the

U.S. Army Engineering and Housing Support Center,

U.S. Air Force Engineering and Services Command, and

U.S. Department of Energy Office of Building Technology

Prepared by the

OAK RIDGE NATIONAL LABORATORY

Oak Ridge, Tennessee 37831

managed by

MARTIN MARIETTA ENERGY SYSTEMS, INC.

for the

U.S. DEPARTMENT OF ENERGY under contract DE-AC05-84OR21400

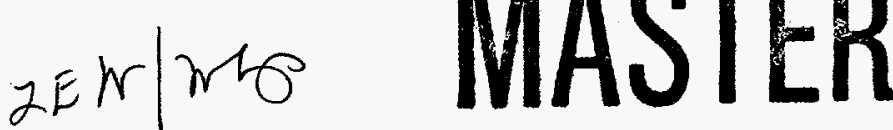





\section{CONTENTS}

LIST OF FIGURES AND TABLES $\ldots \ldots \ldots \ldots \ldots \ldots \ldots \ldots \ldots \ldots$

ACRONYMS $\ldots \ldots \ldots \ldots \ldots \ldots \ldots \ldots \ldots \ldots \ldots \ldots \ldots \ldots \ldots \ldots \ldots \ldots \ldots \ldots$

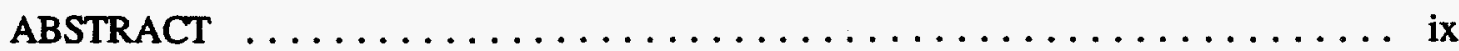

1. BACKGROUND $\ldots \ldots \ldots \ldots \ldots \ldots \ldots \ldots \ldots \ldots \ldots \ldots \ldots \ldots$

2. OBJECTIVES $\ldots \ldots \ldots \ldots \ldots \ldots \ldots \ldots \ldots \ldots \ldots \ldots \ldots \ldots \ldots \ldots$

3. EVALUATION METHODOLOGY $\ldots \ldots \ldots \ldots \ldots \ldots \ldots \ldots \ldots \ldots \ldots$

3.1 MEASURING ENERGY CONSUMPTION $\ldots \ldots \ldots \ldots \ldots \ldots \ldots \ldots \ldots$

3.2 ENERGY MONITORING METHODS $\ldots \ldots \ldots \ldots \ldots \ldots \ldots \ldots \ldots$

3.3 GENERAL COMMENTS ON REVITALIZATION ENERGY MONITORING $\ldots \ldots \ldots \ldots \ldots \ldots \ldots \ldots \ldots \ldots \ldots \ldots \ldots \ldots \ldots \ldots \ldots$

4. ENERGY MONITORING AT MALMSTROM AIR FORCE BASE $\ldots \ldots \ldots \ldots \ldots 11$

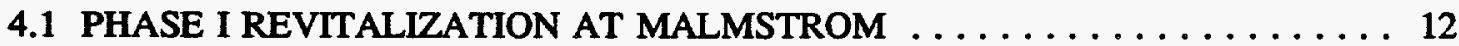

4.2 PHASE II REVITALIZATION AT MALMSTROM . . . . . . . . . . . . 14

4.3 RECOMMENDATIONS FOR MALMSTROM AFB $\ldots \ldots \ldots \ldots \ldots \ldots \ldots$

5. ENERGY MONITORING AT ALTUS AIR FORCE BASE $\ldots \ldots \ldots \ldots \ldots \ldots$

5.1 REVITALIZATION AT ALTUS $\ldots \ldots \ldots \ldots \ldots \ldots \ldots \ldots \ldots \ldots \ldots$

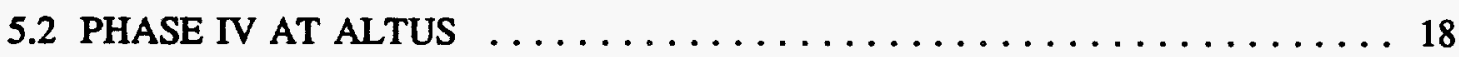

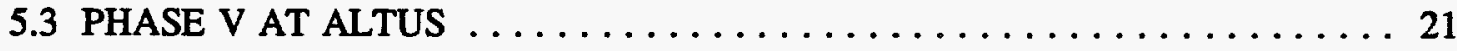

5.4 RECOMMENDATIONS FOR ALTUS $\ldots \ldots \ldots \ldots \ldots \ldots \ldots \ldots \ldots$

6. ENERGY MONITORING AT FORT MONMOUTH $\ldots \ldots \ldots \ldots \ldots \ldots \ldots \ldots$

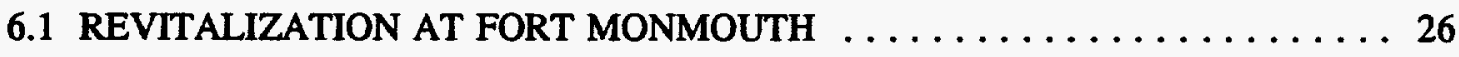

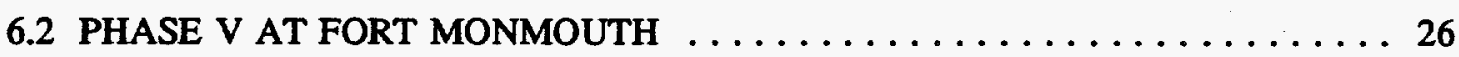

6.3 RECOMMENDATIONS FOR FORT MONMOUTH . . . . . . . . . . . 29

7. DETERMINATION OF SAMPLE SIZE TO OBTAIN VALID RESULTS $\ldots \ldots \ldots 31$



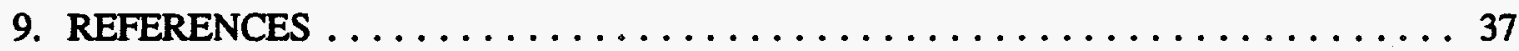

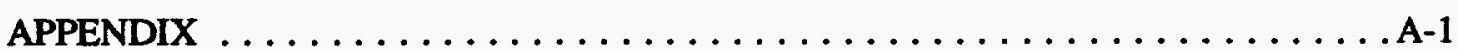




\section{FIGURES AND TABLES}

\section{Figures}

7.1 Sample size necessary to detect a difference between two groups with $95 \%$ confidence ............................. 33

7.2 Probability of an estimate's accuracy when the standard deviation is $8 \ldots \ldots 33$

\section{Tables}

4.1 Makeup of family housing at Malmstrom AFB $\ldots \ldots \ldots \ldots \ldots \ldots \ldots \ldots$

$4.2 \quad$ Housing types in Phase $I$ at Malmstrom AFB $\ldots \ldots \ldots \ldots \ldots \ldots \ldots$

$5.1 \quad$ Makeup of family housing at Altus AFB $\ldots \ldots \ldots \ldots \ldots \ldots \ldots \ldots \ldots$

$5.2 \quad$ History of revitalization work at Altus AFB $\ldots \ldots \ldots \ldots \ldots \ldots \ldots \ldots$

5.3 Method 1 monitoring of Phase IV at Altus AFB $\ldots \ldots \ldots \ldots \ldots \ldots \ldots$

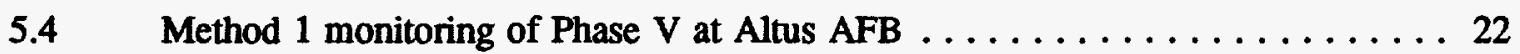

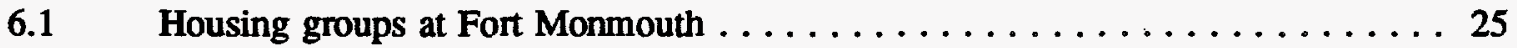

$6.2 \quad$ Revitalization phases at Fort Monmouth $\ldots \ldots \ldots \ldots \ldots \ldots \ldots \ldots \ldots$

$6.3 \quad$ Phase $V$ revitalization project at Fort Monmouth $\ldots \ldots \ldots \ldots \ldots \ldots \ldots$

$6.4 \quad$ Method 1 monitoring of Phase $V$ at Fort Monmouth $\ldots \ldots \ldots \ldots \ldots \ldots$

7.1 EEDO estimates of heating energy savings from houses at Altus AFB $\ldots \ldots 32$

A.1 Proposed military family housing total energy use budget for new construction . . A-1

A.2 DEIS energy use data for potential military base monitoring sites $\ldots \ldots \ldots \ldots$ A-2 


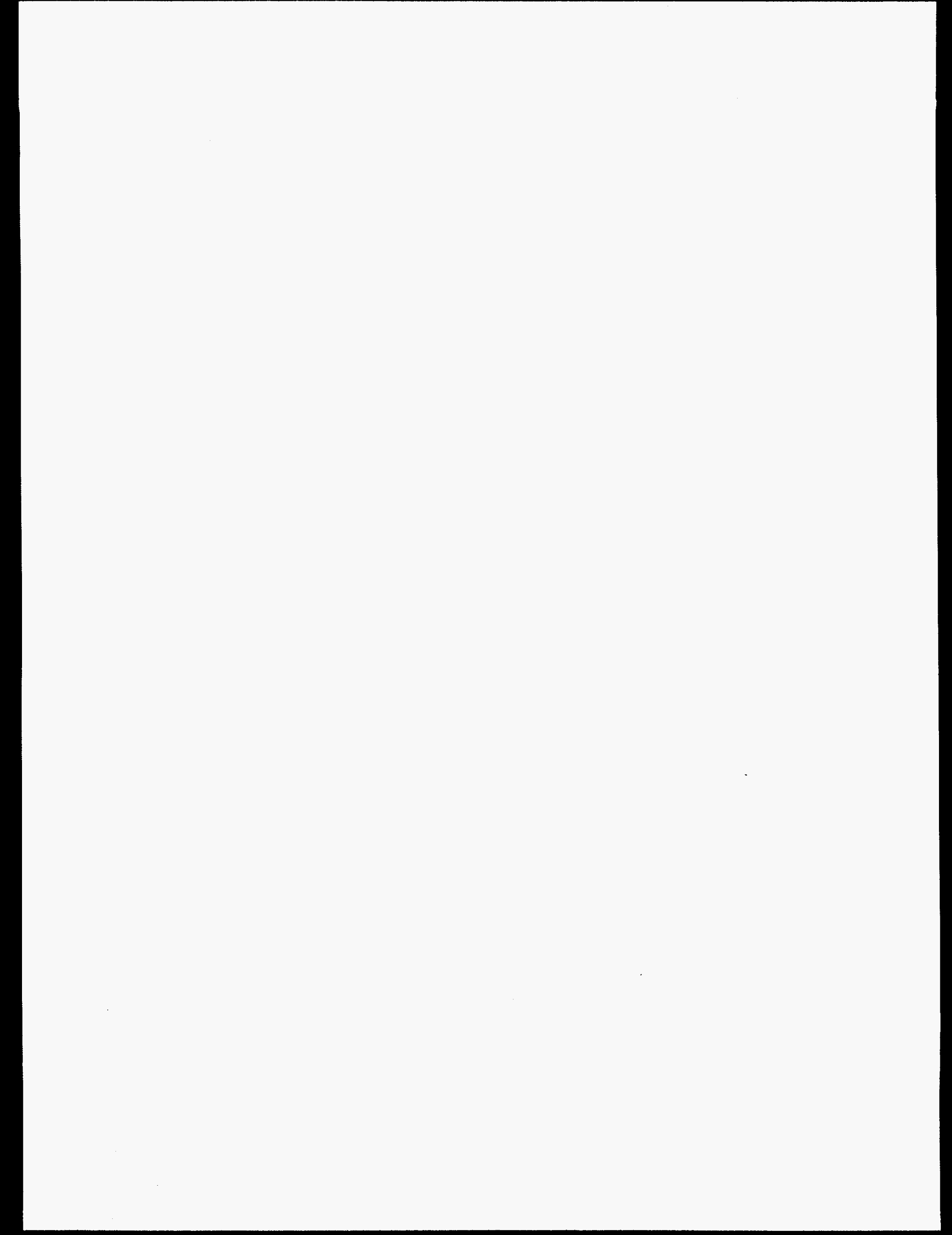




\section{ACRONYMS}

A\&E architectural and engineering

AFB Air Force Base

DEIS Defense Energy Information System

EEDO Energy Economics of Design Options (computer modeling program)

EUB Energy Use Budget (U.S. Department of Defense)

ORNL Oak Ridge National Laboratory 



\begin{abstract}
Oak Ridge National Laboratory is working with the U.S. Army, the U.S. Air Force, and the U.S. Department of Energy to develop a guidebook to be used by architectural and engineering firms in the design phases of military family housing revitalization projects. The purpose of the guidebook is to ensure that energy efficiency is properly addressed in revitalization projects. Monitoring space-heating and cooling energy used in houses both before and after they are revitalized is necessary in order to assess the amount of energy saved by the revitalization process.

Three different methods of conducting monitoring experiments are discussed, as well as the methods of data analysis to be used. Houses will be monitored individually using standard gas and electric meters to obtain heating and cooling data for the houses.

We recommend conducting monitoring programs at Altus Air Force Base, Oklahoma, and Fort Monmouth, New Jersey, because of their project schedules and potential for savings. We do not recommend doing any monitoring at Malmstrom Air Force Base, Montana, because of the relatively small savings that we expect revitalization to accomplish there. We do not recommend seeking out alternative sites for monitoring because of the time required to become familiar with the installation and also because revitalization schedules at altemative sites may be no better than those at the sites we inspected.
\end{abstract}




\section{BACKGROUND}

One of two major tasks to be performed under the Energy Efficiency in Military Family Housing Revitalization and Retrofit Project is the development of a revitalization guidebook for use by architectural and engineering (A\&E) firms in the design phase to ensure that energy efficiency is properly addressed during revitalization. Field monitoring is necessary to confirm that energy savings were achieved by these recommendations. Monitoring involves measuring certain parameters over a period of time and collecting the measurements as data for later analysis so that specific goals can be obtained. The process and scope of monitoring an experiment or a project can be complex and is often not fully understood or appreciated by everyone involved.

The goals of the monitoring and how to go about obtaining them must be clearly established before proceeding. The following are some questions that must be asked:

- What do we want to know and with what accuracy? This is the main reason for doing monitoring.

- How can we learn what we want to know from monitoring? Can the goal be obtained directly, or must a control group be used?

- How long must monitoring be performed? Are there alternative approaches, or can modeling be used to reduce the time?

- What should be measured? Obtaining the main goal may involve the interaction of many parts.

- What instrumentation is necessary to perform monitoring?

- How and how often will the data be collected, and who will collect it?

- How will the data be analyzed?

- How much will the monitoring process and data analysis cost?

- What external constraints exist that can affect monitoring?

Family housing at three military installations-Malmstrom and Altus Air Force Bases (AFBs) and Fort Monmouth-were inspected as part of the development of the revitalization guidebook. We anticipated that revitalization projects scheduled for those installations would be performed after our revitalization guidebook was completed, thus making them good candidates for monitoring. However, uninspected installations could also be good test beds to determine the utility and effectiveness of the guidebook if revitalization designs were developed following the recommendations in the guidebook. 



\section{OBJECTIVES}

Our monitoring goals to support the development of the revitalization guidebook include the following activities:

- $\quad$ evaluating the useability of the revitalization guidebook;

- validating technical procedures and the energy savings achieved from them;

- validating methods used to estimate savings; and

- $\quad$ establishing a baseline energy consumption independent of the Defense Energy Information System (DEIS) data.

To meet these objectives, the monitoring process must provide the following products and information:

- current energy consumptions;

- $\quad$ energy savings from recommendations provided by the revitalization guidebook;

- a comparison between predicted and measured energy savings;

- time and costs associated with performing the recommended measures; and

- feedback from A\&E firms, base organizations, and installation contractors on using the guidebook and its recommendations.

Topics that will not be emphasized in this study include:

- determining specific causes (measures) of energy savings;

- directly measuring the performance of specific measures (although a few measurements to address house air leakage, duct leakage, and heating system efficiencies could be made in a few housing units);

- comparing the current approach to revitalization to an approach that follows the guidebook;

- determining reductions related to electric demand; and

- determining the cost-effectiveness of individual measures. 



\section{EVALUATION METHODOLOGY}

All monitoring plans developed for this project will have to consider the following constraints imposed from various sources:

- the time schedules of the revitalization projects-this will affect what is done, when it is done, and when results will be available;

- housing types and the number of housing units addressed by scheduled revitalization projects;

- the cost of monitoring, which must be maintained to a level consistent with its overall importance in supporting development of the revitalization guidebook;

- the turnover rate of occupants, which can be high in the military; and

- $\quad$ energy savings may be less than expected because prescriptive measures (attic insulation, wall insulation, and high-efficiency equipment) have already been installed, energy deficiencies are house-type dependent, and expectations are based on incorrect DEIS data.

Established schedules of revitalization projects are likely to be a major constraint. Monitoring results cannot be obtained until 1998 on projects that will be designed starting in 1995, with construction to start in 1996. Monitoring results are delayed to 1996 even for projects that are currently at $30 \%$ of design. Altering revitalization designs to include guidebook recommendations and installing instrumentation in time to monitor revitalization projects that are already designed and ongoing will be difficult.

We anticipate that monitoring performed at the installations will require assistance from on-site personnel to oversee meter installations, assist with data collection, provide feedback on revitalization performed following the guidebook, and help us interface with the revitalization contractor.

\subsection{MEASURING ENERGY CONSUMPTION}

Any monitoring projects at the three installations we inspected will include measuring natural gas consumptions of the housing units. Revitalization will significantly affect spaceand water-heating energy consumptions, and natural gas is used for these functions in all houses at both AFBs and in many houses at Fort Monmouth. Natural gas is also scheduled to replace the fuel oil currently being used for space heating at many Fort Monmouth on-post houses.

Installing a gas meter on the supply line of each house is the preferred method to monitor the gas consumption of a housing unit because the meter measures space-heating, water-heating, and base-load gas consumption. Gas meters provide accurate data, and data 
collection is easily performed by a meter reader. An alternate approach is to monitor only space-heating gas consumption using either a separate run-time meter or a commercially available thermostat that measures system on-time. These devices might require occupant assistance to make readings, are not as accurate as gas meters, and do not include whole-house gas consumption.

If fuel-oil consumption needs to be monitored, as it might at Fort Monmouth, either a run-time meter on the oil pump feeding the burner, a thermostat that measures system on-time, fuel-oil delivery data to a dwelling, or a calibrated oil-tank level indicator (with delivery data) could be used. A run-time meter on the oil burner is an accurate method to use, but the data collection process requires someone to read the meter. Meter reading could be intrusive to the occupants, although the meter display could be mounted in a basement window to minimize occupant involvement in the process. A data logger with a call-out modem could be used, which would supply accurate data on a regular basis and also minimize occupant involvement. The data logger is a high-tech solution, but we have used them in the past with very good success.

The importance of monitoring electricity consumption is installation-specific-it depends upon the use of air conditioning. It is less important than monitoring gas consumption at Malmstrom AFB where central air conditioning is not presently installed. It is equally important at Altus AFB, where air conditioners are heavily used, and also at Fort Monmouth, where central air conditioning is being installed during revitalization (even though Fort Monmouth has a fairly moderate cooling season). Revitalization will affect base-load electricity consumption but not to the extent where the change can be easily measured.

Installing an individual house kilowatt-hour (utility-billing-type) meter is the preferred method to monitor electricity consumption of a housing unit, although the same meter could be installed to monitor only air-conditioner electricity consumption if so desired. These meters are easily installed and can be read by meter readers. A run-time meter or a commercially available thermostat is not an attractive option because the power used by an air conditioner increases with higher outdoor temperatures.

Billing data cannot be used to track gas and electricity consumptions because military family housing does not presently have billing meters on individual housing units. Some exceptions to this may exist, but in these few cases the meters were probably installed as part of a previous experimental monitoring program.

Monitoring gas and electricity consumptions of revitalized houses by using several meters installed on the main gas supply lines or electrical grid, rather than metering individual units, was considered. This approach is generally not feasible because of the layout of the gas and electrical lines in the housing areas and because units scheduled for revitalization are often spread throughout the housing area. The main family housing gas and electric meters cannot be effectively used because the number of revitalized units are a small percentage of the total number of housing units monitored by these meters. 


\subsection{ENERGY MONITORING METHODS}

One method to measure the energy savings due to revitalization-we will call it Method 1-is to monitor individual housing units and collect energy consumption data for as much of a full heating or cooling season as possible, both before and after revitalization takes place. This direct method requires only that the results be normalized for the severity of the weather from one season to the next. Normalized energy consumptions before and after revitalization are estimated for each housing unit by regressing a weekly energy consumption vs a weekly outdoor temperature (or better yet by the indoor-outdoor temperature difference if the indoor temperature is known). These consumptions can be further normalized by floor area and/or degree days if desired. Energy savings and group averages can be easily calculated using a standard weather year (Typical Meteorological Year available from the National Oceanic and Atmospheric Administration) as a basis for the comparison. This type of analysis usually works very well as a heating normalizer but not quite as well as a cooling normalizer (although it is still adequate for cooling).

If a control group of houses similar to those being revitalized is available, it can be monitored in the same manner as the revitalized group over the same two heating or cooling seasons. The data are analyzed and normalized in the same manner as for the revitalized houses. Comparisons are made between the control group from one season to the next, as well as between the control and revitalized groups for the test seasons in question. The control group adds credence to results if its energy performance is similar from one season to the next, or it tells how much scatter (or noise) to expect in the revitalized comparison if its seasonal results differ. The use of a control group necessitates more houses being monitored, which increases costs but does provide more solid results.

The advantages of Method 1 are that average savings can be calculated for each type of housing in addition to a total group average, and it is a traditional design with known statistical foundations. The disadvantages are that it requires an extended monitoring period before and after the units are revitalized, covering two full (consecutive) heating or cooling seasons, in order to obtain the necessary data to make comparisons. Revitalization work should be completed in the off-season in order to minimize monitoring periods. Any revitalization work performed during a heating or cooling season will usually cause insufficient data to be obtained-a situation requiring a wait for the next full heating or cooling season.

A second method, referred to here as Method 2, is a test-reference design. Energy consumption data are collected on a group of revitalized housing units for as close as possible to a full heating or cooling season following revitalization and are compared to data collected from the same time period from a group of identical but unrevitalized units. Because data are collected on both groups of houses at the same time in Method 2, no normalization for weather is required. However, a normalizing factor such as floor area should be used. Only group averages, rather than unit-by-unit values, can be estimated. 
The two groups of housing units should be as identical as possible when using Method 2. It can be risky to compare consumptions of revitalized housing units of one type to consumptions of unrevitalized housing units of another type without first establishing that their pre-revitalization consumptions were the same. The results of such an approach could be highly questionable.

Both Method 1 and Method 2 are traditional and statistically valid experimental designs. Method 1 is inherently more accurate because results are calculated on the same unit-by-unit basis before calculating group averages, whereas only group averages are available from Method 2. Method 1 requires weather normalization, while Method 2 requires area (square footage) normalization for the comparison. Method 2 needs only one heating or cooling season of monitoring but requires monitoring twice as many houses as Method 1 (if Method 1 does not use a control group).

A third method, Method 3, uses elements of Methods 1 and 2 combined in a less rigorous approach. Each housing unit to be revitalized is monitored during the construction period (usually about 18 months) such that energy consumption data before and after revitalization are collected for each unit. Some units will have little pre-revitalization data but more post data, while others have more pre data and little post data. A very limited Method 1 analysis can be performed on a small subset of the monitored housing units, and a less rigorous Method 2 analysis can be performed on a medium-sized subset of houses, some of which are probably not identical. Useful data are not collected during the time taken by the contractor to revitalize a house, typically about 3 months. A 3-month period with no data minimizes the useful inclusion of houses in locations undergoing mild heating or cooling seasons. Method 1 will be of limited use even in locations with long heating or cooling seasons.

Method 3 makes use of more limited data (data that do not cover an entire heating or cooling season for a house), provides group averages, and provides earlier results than Methods 1 and 2. The disadvantages of Method 3 are that its statistical basis is not as rigorous as that of Methods 1 and 2, results will be less accurate, average savings by housing type may be uncertain because of the small number of units involved and their limited data, and group averages may end up being based on different housing units because the heating and cooling seasons are shorter than the construction period.

An alternative method to the three long-term monitoring methods discussed here uses short-term (2- or 3-day) monitoring of each house, both before and after revitalization. The results obtained by short-term monitoring are envelope parameters; no lifestyle effects are obtained. The testing is usually done one house at a time because of the equipment involved.

The main advantage of short-term monitoring is that it only takes 2 or 3 days to accomplish. Disadvantages are that it is expensive if many houses are monitored, the house must be unoccupied during the 2- or 3-day monitoring period, the method requires highly trained technicians with specialized equipment to conduct the testing, an advanced computer program for analysis and modeling is needed to obtain results, and the results may be suspect 
if the outdoor temperature fluctuations are narrow during testing. This technology is not widely used and is still in the development stages. Short-term monitoring is a very attractive option, but we feel that it will not generally be useful in this work.

Housing units that were revitalized following current practices can be compared to units that were revitalized following the revitalization guidebook by using any of the three methods, provided both types of revitalizations are performed during the same season. We do not recommend this design because of the following reasons:

- The important research question to be addressed from monitoring is the efficiency improvement obtained from the best revitalization strategy possible. The performance of an intermediate strategy may be of academic interest but not of practical interest.

- The number of units revitalized under each approach is essentially reduced by half, which may be too small for good statistical analysis. Half the units would be revitalized to less than optimum efficiency (assuming the guidebook recommendations are significantly different than what would have occurred under the current approach).

- Housing units would have to be scheduled for revitalization in a set order for the analysis to work for Method 2. In most cases, there is little control over which housing units get revitalized and when, because vacancy is the primary factor.

\subsection{GENERAL COMMENTS ON REVITALIZATION ENERGY MONTORING}

Because of the uncertainty of scheduling and funding, as well as unexpected problems arising during construction, we recommend monitoring the first phases possible at an installation where revitalization work is known to be under way. Later phases may be scheduled but are often delayed for the reasons just mentioned. Meters purchased for initial phases can always be used for subsequent phases. Once they have been installed, meters can be read at the beginning and end of each heating/cooling season, thus providing consumption data for additional periods after revitalization has been done.

Seeking out installations other than the three that we have inspected for monitoring purposes may not speed up obtaining results because of the front-end work involved in acquainting ourselves with the installation and the personnel involved. 







\section{ENERGY MONITORING AT MALMSTROM AIR FORCE BASE}

Malmstrom AFB is located in Great Falls, Montana, about $\mathbf{4 0}$ miles east of the Rocky Mountains. It averages 7671 heating degree days and 370 cooling degree days.' This climate provides a high heating load for the housing at Malmstrom but a relatively small cooling load.

Table 4.1 identifies the main housing group classifications at Malmstrom AFB. Most of the Capehart housing has basements, while the relocatables are located on crawl spaces. All heating systems are forced-air gas-fired units, and all domestic hot water is heated with gas. There is no whole-house air conditioning at Malmstrom, but it is being considered as an option in the revitalization process.

Table 4.1. Makeup of family housing at Malmstrom AFB

\begin{tabular}{lcccc}
\hline \multicolumn{1}{c}{ Housing group } & $\begin{array}{c}\text { No. of } \\
\text { buildings }\end{array}$ & No. of units & Year built & $\begin{array}{c}\text { Type of } \\
\text { housing }\end{array}$ \\
\hline On-base Capehart & 76 & 150 & 1959 & Duplex/single \\
Off-base Capehart & 281 & 560 & 1949 & Duplex \\
Lincoln Drive Wherry & 43 & 400 & 1951 & Multi \\
Malmstrom Drive Wherry & 40 & 92 & 1949 & Multi \\
Relocatable & 100 & 200 & 1965 & Duplex \\
Washington Circle & 4 & 4 & 1960 & Single \\
\multicolumn{1}{c}{ All groups } & 544 & 1406 & & \\
\hline
\end{tabular}

Analysis of available DEIS data (see Appendix, Table A.2) indicated that the family housing gas consumption at the base was high relative to other bases. The total energy consumption was about twice that of the proposed U.S. Department of Defense Energy Use Budget (EUB) of $55 \mathrm{MBtu} / \mathrm{kSF} \cdot$ year (see Appendix, Table A.1). Our site inspections revealed three possible reasons for this:

- Family housing gas consumption was determined using an outdated formula applied to base gas consumption. Two gas meters located at the base gas-line entrance measured family housing gas consumption, and although the meters were read on a regular basis, 
the readings were not used. One of these meters was not recording because it was valved off and bypassed. The meters have since been calibrated, are operational, and are now being used to report family housing gas consumption. Future data will be more accurate than previous data and will better describe the family housing gas consumption.

- Heated basement areas were not included in the floor area normalization. Basements are present in half the housing units at Malmstrom, and each has supply registers to provide heating. If this heated basement area were included in the normalizations, consumption intensity for Malmstrom would be much lower.

- The main gas supply for the base hospital comes from the family-housing gas main, as does part of the gas supply for a base power plant. These are loads that should be accurately measured and deleted from the family housing consumption.

A monitoring program at Malmstrom would focus on obtaining weekly gas consumptions of the housing units, especially during the winter months. Because air conditioners are not currently installed in these housing units, there is no need to monitor electricity consumption unless air conditioners are installed as part of the revitalization.

\subsection{PHASE I REVITALIZATION AT MALMSTROM}

No previous revitalization has taken place at Malmstrom, although many projects have been completed that addressed energy and aesthetic topics. Phase $I$ is therefore the first official revitalization project. Construction was scheduled to begin Spring 1994 and continue for 18 months, but recent changes in the design have moved construction farther back into 1994. Table 4.2 contains the specific makeup of the houses in Phase $I$.

Types B4 and B5 units are unique housing types (only one of each is on base) located off Aspen Street. The rest of the houses are from the off-base Capehart Group and are located on Gumwood and Locust Streets. There are many other type C, D, E, and G units on the base that are not being revitalized under this phase, which would make a Method 2 monitoring scheme feasible.

We expect that attic insulation, wall insulation, and high-efficiency condensing gasfurnace upgrades have already been performed in these housing units based on our site inspections. We also expect these units to have a design problem with the remm airdistribution system (attic air is drawn into the retum system) and an inadequate thermal boundary in the basement (the basements are heated, but no basement insulation is present). The thermal boundary problem should be addressed in the new design changes, as a family 
Table 4.2. Housing types in Phase I at Malmstrom AFB

\begin{tabular}{cccc}
\hline $\begin{array}{c}\text { Type of } \\
\text { housing }\end{array}$ & $\begin{array}{c}\text { No. of } \\
\text { buildings }\end{array}$ & $\begin{array}{c}\text { Units per } \\
\text { building }\end{array}$ & $\begin{array}{c}\text { Total } \\
\text { units }\end{array}$ \\
\hline B4 & 1 & 1 & 1 \\
B5 & 1 & 1 & 1 \\
C & 12 & 2 & 24 \\
D & 6 & 2 & 12 \\
E & 4 & 2 & 8 \\
E & 1 & 1 & 1 \\
E & 1 & 1 & 1 \\
G & 5 & 2 & 10 \\
Total & 31 & & 58 \\
\hline
\end{tabular}

room will be located in the basement to reduce costs instead of added on externally, which will save energy, too, as a by-product. The new design will also include a game room in the basement because a new arctic living supplement (applying to locations with at least $\mathbf{7 5 0 0}$ heating degree days) allows an additional $300 \mathrm{ft}^{2}$ of area for a recreation room. We expect that these changes will add wall insulation and retum-air registers to the basements, thus overcoming the thermal boundary deficiencies that we found.

Method 1 can be used to monitor the houses revitalized under this phase only if construction starts after Spring 1995. Pre-revitalization monitoring would occur from Fall 1994 to Spring 1995. Revitalization work would be performed from Spring 1995 to Fall 1996. Postrevitalization monitoring would occur from Fall 1995 to Spring 1996 for about a third of the units, and from Fall 1996 to Spring 1997 for the remaining units. Interim results would be available Summer 1996, with full results available Summer 1997. The critical item for this monitoring method is to have gas meters installed on the housing units and data collection started in November 1994.

A test-reference design (Method 2) can also be used. Data would be collected from Fall 1996 to Spring 1997, with results available Summer 1997. As an option, data could be 
collected from Fall 1995 to Spring 1996 on units revitalized by this start date (about one-third of the units) and a corresponding reference group, with results available Summer 1996.

Method 3 might also be used. Data would be collected on all housing units starting Spring 1995 and ending Fall 1996, coincident with the construction period. Results would be available Summer 1996 because the only winter season during the construction period ends with Spring 1996.

\subsection{PHASE I REVITALIZATION AT MALMSTROM}

The design for this phase is scheduled to begin in 1995, with construction most likely to begin at the end of Phase I and continue for 18 months, from Fall 1996 to Spring 1998. Results of monitoring using Method 3 would be available in Summer 1998 or Winter 1998/99; results for Methods 1 and 2 would not be available until Summer 1999. This phase will likely address housing units either similar to those addressed under Phase I (same levels of inefficiency and types of problems) or units without the major distribution system problems because they have a slightly different design.

\subsection{RECOMMENDATIONS FOR MALMSTROM AFB}

We do not recommend a monitoring program at Malmstrom for the following reasons:

- It may not be possible to measure with statistical certainty the small energy savings expected there (on the order of $10 \%$ or less). Previous projects have already addressed many efficiency opportunities, leaving duct repairs and basement insulation as the main problems.

- Project sponsors do not want to wait until Summer 1998 or later for results from Phase II. We expect Phase II energy savings to be similar to those of Phase I.

If Phase $I$ is to be monitored despite our recommendations, efficiency recommendations for repairing the retum-air distribution systems need to be developed and incorporated into the revitalization design as soon as possible. These recommendations may have to be developed before the revitalization design guidebook is completed. Some extra costs will be incurred by the A\&E firm to change the design at this late date, although the design is currently being modified for economic reasons. 
We suggest the following monitoring plan, keeping in mind our concem about the statistical uncertainty of the results:

- Install gas meters by November 1994 on all housing units scheduled for revitalization so that Methods 1 and 3 can be used.

- Collect data from Fall 1994 to Spring 1996. Interim results from a Method 1 analysis on about 20 housing units will be available Summer 1996, as will the final results of the less rigorous Method 3.

- Decide Fall 1995 if unrevitalized housing units identical to the units revitalized to that date (about one-third of the units) should be metered. This would allow a Method 2 analysis to be performed and compared to the Method 1 interim results Summer 1996.

- If additional results are desired, continue monitoring through Spring 1997. A complete Method 1 analysis can be performed on all 58 housing units, with results available Summer 1997.

- If meters cannot be installed by November 1994, then

- Decide Fall 1995 if unrevitalized housing units identical to the units revitalized to that date (about one-third of the units) should be metered. This would allow a Method 2 analysis to be performed and compared to the Method 1 interim results Summer 1996.

- Decide Fall 1996 if more data are required. If so, install gas meters on all revitalized housing units without meters and a corresponding reference group by September 1996 so that Method 2 can be used. Collect data from Fall 1996 to Spring 1997, such that results are available Summer 1997.

Oak Ridge National Laboratory (ORNL) will be responsible for the following items to implement the monitoring:

- Obtain a listing of the houses that will be revitalized along with the best estimate of when each house will be revitalized.

- Determine which of the houses should be monitored based on the monitoring method to be used.

- Obtain permission from the proper base authority to install the meters.

- Discuss with base personnel who would be an appropriate contractor to install the gas and/or electric meters. Subcontract with vendor directly or with the base to install and check out the meters. 
- Purchase (or have the contractor purchase as part of subcontract) the gas and electric meters.

- Make arrangements with base personnel to have the meters read on a weekly basis. This may require another subcontract on our part if base personnel cannot assist us.

- $\quad$ Arrange to have the meter readings sent to Oak Ridge on a weekly basis.

- Leave all meters in place after monitoring is completed unless base requests their removal. We will subcontract to have this done if necessary.

Malmstrom AFB will be responsible for the following items:

- Assist us in meter installation by using their present contractor or identifying a contractor for us to use.

- Help us to get the guidebook revitalization recommendations put in the revitalization design.

- Perform weekly meter readings and send us the data, or identify a subcontractor for us to hire. 


\section{ENERGY MONITORING AT ALTUS AIR FORCE BASE}

Altus AFB is located in Altus, a small town in the southwest comer of Oklahoma. It averages 3346 heating degree days and 2347 cooling degree days annually. ${ }^{1}$ The climate at Altus provides the housing with a rather high cooling load but a relatively moderate heating load.

Table 5.1 shows the two major groupings for the housing at Altus. Altus has 800 housing units, with 700 on-base Capehart units and 100 off-base Bicentennial duplex units. The total living area is 1.11 million $\mathrm{ft}^{2}$, and all housing is slab-on-grade. Built in the $1950 \mathrm{~s}$, the Capeharts are all one-story, mostly single-family detached with a garage. They originally all had horizontal gas-fired forced-air furnaces in the attics, gas-fired water heaters in the garages, and central air conditioners. Approximately two-thirds of the Capehart units have already been revitalized under various projects.

Table 5.1. Makeup of family housing at Altus AFB

\begin{tabular}{lcccc}
\hline Housing group & $\begin{array}{c}\text { No. of } \\
\text { buildings }\end{array}$ & $\begin{array}{c}\text { No. of } \\
\text { units }\end{array}$ & Year built & Type of housing \\
\hline On-base Capehart & 665 & 700 & 1950 s & $\begin{array}{l}630 \text { single } \\
35 \text { duplex }\end{array}$ \\
Off-base Bicentennial & 50 & 100 & 1977 & Duplex \\
All groups & 715 & 800 & & \\
\hline
\end{tabular}

The Bicentennials are either single-story or two-story duplex buildings that were built in the 1970s. Each Bicentennial housing unit has a gas-fired fumace with humidifier and gasfired water heater sharing the same closet, as well as a central air conditioner.

DEIS data from Table A.2 show an annual total reported consumption of $100 \mathrm{MBtu} / \mathrm{kSF}$ for 1992. This is much higher than the EUB of $55 \mathrm{MBtu} / \mathrm{kSF}$ (Table A.1) for an Altus-type climate. A closer look at Table A.2 shows that the energy used for heating appears high, while the electrical usage is more reasonable. The DEIS data for Altus should be accurate, as central gas and central electric meters monitor the family housing sector. Both meters are calibrated regularly, having last been done in June 1993.

Our inspections of the family housing at Altus showed that the houses were relatively air-tight but had substantial duct leakage, leakage paths to attics through interior walls, bypasses, and sundry other problems resulting from furnaces being located in attics. After 
analyzing our inspection data, we concluded that a main area of energy savings potential at Altus is contained in the forced-air distribution systems (ducts) that are located in the attics of the Capehart houses. We found many damaged ducts, and attic leakage paths were common in the retum-air sides of distribution systems, even in those houses that had recently been revitalized.

New high-efficiency air-conditioner replacements will also be a source of energy savings, because most present air conditioners, although working properly, are older and of relatively low efficiency. The energy savings potential of the new gas furnaces being installed away from the current attic locations of the old furnaces is also good-mainly because they will be much easier to install and service properly in their new locations.

\subsection{REVITALIZATION AT ALTUS}

Table 5.2 presents a history of the revitalization work done to date, the ongoing work, and the future revitalization phases at Altus. Phases I, II, and III have been completed and involved -465 housing units, with work beginning in 1983. Phase IV is currently under way, and Phase $V$ is in the design stages.

An ongoing project (concurrent with the revitalization work) at Altus scheduled to be completed by the summer of 1994 involves burying all power lines in the on-base family housing area and installing electric meter bases on the housing units. This project will facilitate and reduce costs of installing electric meters on any monitored housing units.

It is not unusual to have additional projects run concurrently with revitalization work on a military installation. The prime reason for this situation is the sometimes short-notice availability of funding for a project.

\subsection{PHASE IV AT ALTUS}

Phase IV involves 113 houses, started construction in September 1993, and involves E, F, G, H, and L houses. Also, some $R$ and $S$ units that have been previously revitalized will have their furnaces replaced and moved from the attic to an isolated furnace room at the rear of the garage during this phase. Twenty houses are currently being revitalized at any one time. The first unit should be completed in December 1993 and returned to base housing in exchange for an unrevitalized house. Additional revitalized houses will be returned in exchange for unrevitalized houses on about a 5 day per unit basis thereafter. Phase IV should be completed in about 18 months (March 1995).

A monitoring plan using Method 1 was devised for Phase IV during the fall of 1993 and is shown in Table 5.3. The plan called for installation of gas meters in all 113 houses by the end of November 1993, so that monitoring of whole-house gas usage could commence on 
Table 5.2. History of revitalization work at Altus AFB

\begin{tabular}{|c|c|c|c|c|c|c|c|c|c|}
\hline \multirow[b]{2}{*}{ Phase } & \multirow[b]{2}{*}{ Year } & \multicolumn{8}{|c|}{ Housing type and number of units revitalized } \\
\hline & & Type I & Type J & Type $\mathbf{K}$ & Type R & Type S & Type T & Type $\mathbf{M}$ & Total \\
\hline \multicolumn{10}{|c|}{ Completed Phases } \\
\hline I & 1983 & & & & 74 & 74 & & & 148 \\
\hline II & 1985 & & & & 28 & 15 & 108 & & 151 \\
\hline III & 1989 & 45 & 46 & 49 & & 8 & & 18 & 166 \\
\hline \multirow[t]{2}{*}{ Totals } & & 45 & 46 & 49 & 102 & 97 & 108 & 18 & 465 \\
\hline & & \multicolumn{8}{|c|}{ Housing type and number of units revitalized } \\
\hline Phase & Year & Type E & Type F & Type G & Type H & Type L & & & Total \\
\hline \multicolumn{10}{|c|}{ Ongoing Phase } \\
\hline \multirow[t]{2}{*}{ IV } & 1993 & 25 & 24 & 21 & 26 & 17 & & & 113 \\
\hline & & \multicolumn{8}{|c|}{ Housing type and number of units revitalized } \\
\hline Phase & Year & Cma & Type U & Type $\mathbf{W}^{b}$ & Type V & Type S & $\mathrm{JA}^{b}$ & $\mathrm{SA}^{b}$ & Total \\
\hline \multicolumn{10}{|c|}{ Future Phases } \\
\hline $\mathbf{V}$ & 1995 & 9 & 19 & $70(35)$ & 16 & 8 & & & 122 \\
\hline VI & 一 & & & & & & $70(35)$ & $30(15)$ & 100 \\
\hline
\end{tabular}

${ }^{\circ} \mathrm{Cmd}=$ Command Circle with housing types A (1), B (1), C (3), D (2), and HA (2).

'Duplexes containing two housing units per building. 
Table 5.3. Method 1 monitoring of Phase IV at Altus AFB

\begin{tabular}{lllll}
\hline & \multicolumn{1}{c}{$\begin{array}{c}\text { Dec. 1993- } \\
\text { March 1994 }\end{array}$} & $\begin{array}{c}\text { April 1994 } \\
\text { mid-June 1994 }\end{array}$ & $\begin{array}{c}\text { Mid-June } \\
\text { 1994 } \\
\text { Nov. 1994 }\end{array}$ & $\begin{array}{r}\text { Dec. 1994- } \\
\text { April 1995 }\end{array}$ \\
\hline Number of houses & 30 & 19 & 42 & 22 \\
ORNL input & No & Maybe & Yes & Yes \\
Pre-heating data & None & None & Winter '93/94 & Winter '93/'94 \\
Pre-cooling data & None & None & None & Summer '94 \\
Post-heating data & Winter '94/'95 & Winter '94/'95 & Winter '94/'95 & Winter '95/96 \\
Post-cooling data & Summer '94 & Summer '94 & Summer '95 & Summer '95 \\
Heating results by & None & None & Summer '95 & Summer '96 \\
Cooling results by & None & None & None & Winter '95 \\
\hline
\end{tabular}

December 1,1993 . It would have been necessary to introduce a modification into the builder's contract in order to include energy-efficiency recommendations into Phase IV, with probably no input into the first 30 or so housing units being possible.

Monitoring from December 1993 to October 1995 would have allowed heating results for 42 houses and cooling results for 22 houses by December 1995. Continued monitoring until April 1996 would have provided additional heating results for 22 more houses by July 1996.

A Method 2 approach to monitoring could not be used because there were no remaining unrevitalized reference housing units of the proper types.

Charles Fields, the deputy construction engineer at Altus, is eager to participate in the monitoring. However, he informed us that his finances were at the statutory spending limit for Phase IV. Some potential problems involving lead paint on the unrevitalized houses have also surfaced, and these may slow progress and incur even more costs. Therefore, it was not possible to implement our plan in Phase IV.

If monitoring were done from December 1993 to April 1996, the following data would be obtained:

- heating results for 42 houses by July 1995 ,

- heating results for 64 houses by July 1996, and

- cooling results for 22 houses by December 1995. 
If monitoring were done from December 1993 to October 1995, the following could be obtained:

- heating results for 42 houses by July 1995 , and

- cooling results for 22 houses by December 1995.

\subsection{PHASE V AT ALTUS}

Phase $\mathrm{V}$ involves 122 housing units and looks more promising than Phase IV as far as our starting time is concemed, but it does add an additional 1-year delay over Phase IV before results can be obtained. The A\&E firm for Phase V, C. H. Guemsey of Oklahoma City, started design work in early October 1993 and is scheduled to complete the design by June 1994. Construction will start at the conclusion of Phase IV, which should be about April 1995. Construction under Phase V will continue until about October 1996. ORNL has been in contact with Guemsey and has supplied them with recommendations concerning energyefficiency improvements along with a draft copy of the revitalization guidebook. The extent to which this input is being used is unknown at present.

Table 5.4 contains a summary of our monitoring plan for Phase V using Method 1. Electric meters must be installed on all houses scheduled for revitalization by June 1994, and gas meters must be installed by November 1994. Monitoring done from June 1994 to September 1996 can provide cooling results for 102 units along with control data from 20 units, as well as heating results for 49 units along with control data from 53 units in December 1996. If monitoring is continued until April 1997, then heating results from an additional 53 units (but with no controls) would be available in June 1997.

\subsection{RECOMMENDATIONS FOR ALTUS}

We recommend initiating monitoring at Altus for Phase $\mathrm{V}$ and conducting monitoring from June 1994 through September 1996. This will allow time to discuss the project with the A\&E firms, insert energy guidelines into the design, and install necessary metering. Sufficient data will be obtained from 53 units in cooling only, and 49 units in both heating and cooling, in order to determine the energy savings from the revitalization in December 1996.

Monitoring Phase IV can be pursued if December 1996 is not an acceptable date for results. We do not recommend this approach for several reasons.

- Results available in December 1995 would be based on 20 houses for heating only, and 22 houses for both heating and cooling. 
Table 5.4. Method 1 monitoring of Phase $V$ at Altus AFB

\begin{tabular}{|c|c|c|c|c|}
\hline & $\begin{array}{l}\text { June } 15,1995 \\
\text { Sept. } 30,1995\end{array}$ & $\begin{array}{l}\text { Oct. } 1,1995- \\
\text { Nov. } 30,1995\end{array}$ & $\begin{array}{l}\text { Dec. } 1,1995- \\
\text { June } 14,1995\end{array}$ & $\begin{array}{l}\text { June } 15,1995 \\
\text { Sept. } 30,1996\end{array}$ \\
\hline Number of houses & 33 & 16 & 53 & 20 \\
\hline $\begin{array}{l}\text { ORNL guidebook } \\
\text { input }\end{array}$ & Yes & Yes & Yes & Yes \\
\hline Pre-heating data & Winter ' $94 / 95$ & Winter '94/'95 & Winter '94/95 & $\begin{array}{l}\text { Winter '94/’95, } \\
\text { '95/'96 }\end{array}$ \\
\hline Pre-cooling data & Summer ' 94 & Summers '94, '95 & Summers '94, '95 & Summers '95, '96 \\
\hline Post-heating data & Winter '95/'96 & Winter '95/96 & Winter '96/'97 & Winter '96/97 \\
\hline Post-cooling data & Surmmer '95 (4), '96 & Summer '96 & Summer '97 & Summer '97 \\
\hline Heating results by & Summer '96 & Summer '96 & Summer '97 & Summer '97 \\
\hline Cooling results by & Winter $96 / 97$ & Winter ' $96 / 97$ & Winter $96 / 97$ & Winter '97/98 \\
\hline
\end{tabular}

- The chances of monitoring in Phase IV are very unlikely because of statutory spending limits on the project.

- It will be extremely difficult to arrange subcontracting for meter installations in a timely fashion.

ORNL will be responsible for the following items to implement any monitoring done at Altus AFB:

- Ensure that the A\&E firms will use the revitalization guidebook in their design and that any recommendations are acceptable to base engineering.

- Provide any additional specifications and details to ensure that the job will be done properiy.

- Obtain a listing of the houses that will be revitalized along with the best estimate of when each house will be revitalized.

- Determine which of the houses should be monitored based on the monitoring method to be used.

- Obtain permission from the proper base authority to install the meters.

- Discuss with base personnel who would be an appropriate contractor to install the gas and/or electric meters. Subcontract with either the vendor directly or with the base to install and check out the meters. 
- Purchase (or have the contractor purchase as part of the subcontract) the gas and electric meters.

- Make arrangements with base personnel to have the meters read on a weekly basis. This may require another subcontract on our part if base personnel cannot assist us.

- $\quad$ Arrange to have the meter readings sent to Oak Ridge on a weekly basis.

- Plan to leave all meters in place after monitoring is completed unless the base requests their removal. We will subcontract to have this done if necessary.

Altus AFB will be responsible for the following items:

- Assist in meter installation by using their present contractor or identifying a contractor for us to use.

- Help to get the guidebook revitalization recommendations put in the revitalization design.

- Perform weekly meter readings and send us the data, or identify a subcontractor for us to hire.

If monitoring were done from June 1994 to April 1997, the following data could be obtained:

- cooling results for 4 units in December 1995, along with control data for 89 units;

- cooling results for 102 units in December 1996, along with control data from 20 units;

- heating results for 49 units in June 1996, along with control data from 53 units; and

- heating results from 102 units in June 1997 (no control data).

If monitoring were done from June 1994 to September 1996, the following data could be obtained:

- cooling results for 4 units in December 1995, along with control data for 89 units;

- cooling results for 102 units in December 1996, along with control data from 20 units; and

- heating results for 49 units in June 1996, along with control data from 53 units. 


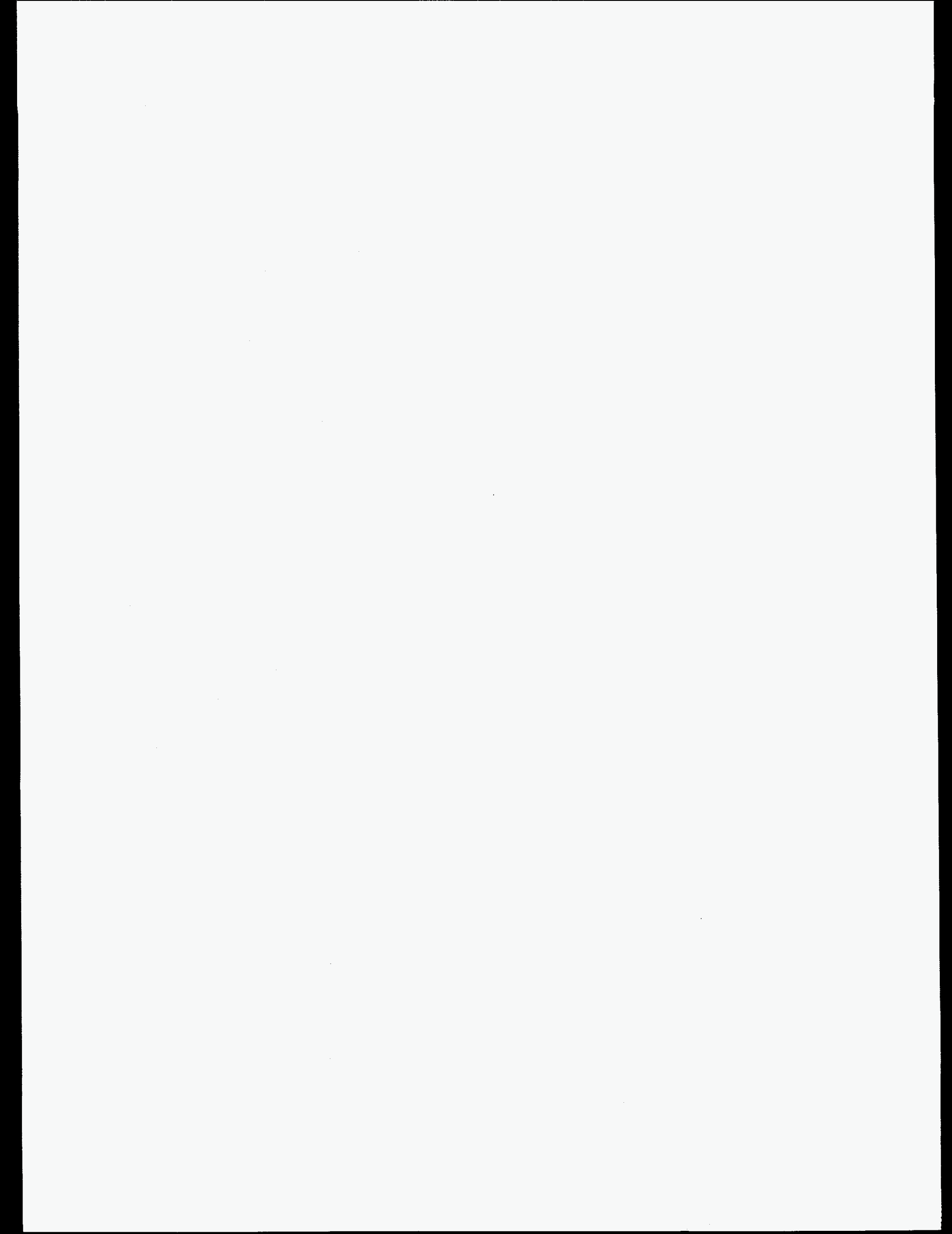




\section{ENERGY MONITORING AT FORT MONMOUTH}

Fort Monmouth is located near Eatontown in New Jersey, about 30 miles southeast of Newark and very close to the ocean. It averages 5128 heating degree days and 770 cooling degree days annually. ${ }^{1}$ This climate provides the housing with a moderate heating load and a mild cooling load.

The housing at Fort Monmouth is divided into 17 different areas, but there are three major groupings (see Table 6.1). The main-post housing is generally vintage, while the offpost housing (military housing located off the main post) was built under the Capehart and Wherry funding plans.

Table 6.1. Housing groups at Fort Monmouth

\begin{tabular}{lcccl}
\hline Housing group & $\begin{array}{c}\text { No. of } \\
\text { buildings }\end{array}$ & $\begin{array}{c}\text { No. of } \\
\text { units }\end{array}$ & Year built & Type of housing \\
\hline Main-post & 54 & 120 & $1925-51$ & Duplex/multifamily \\
Charles Woods & 118 & 536 & $1958-71$ & Multifamily \\
Howard Commons & 52 & 486 & 1958 & Multifamily \\
\multicolumn{1}{c}{ All groups } & 224 & 1142 & & \\
\hline
\end{tabular}

Main-post housing units generally have basements and oil-fired hydronic heating systems, while Charles Woods and Howard Commons housing units have slab-on-grade or crawl-space foundations and gas-fired, forced-air heating systems with central air conditioners. Natural gas is used for heating most domestic hot water and for cooking. The total conditioned floor area is 1.643 million square feet.

DEIS data (see Appendix, Table A.2) show that the total energy consumption reported at Fort Monmouth was $151 \mathrm{MBtu} / \mathrm{kSF}$ in 1992, a value much higher than the EUB for Fort Monmouth of $45 \mathrm{MBtu} / \mathrm{kSF}$. We discovered that the DEIS data on family housing were being reported incorrectly. When the data are corrected, though, they will still be much higher than the $45 \mathrm{MBtu} / \mathrm{kSF}$ EUB value.

Our inspections at Fort Monmouth also revealed that most housing units had inadequate insulation. Wall insulation was essentially nonexistent in the main-post housing, and attic insulation was often lacking. The housing was marginally air-tight, attic bypasses were found, and duct leakage was widespread. 


\subsection{REVITALIZATION AT FORT MONMOUTH}

A total of eight phases are scheduled for the revitalization process at Fort Monmouth (see Table 6.2). As of March 1993, three phases of revitalization involving 365 housing units have been completed, all located off the main-post area; Phase IV construction is under way at Howard Commons, involves 124 houses, and is roughly half completed (as of January 1994). When Phase IV is completed, all of Howard Commons will have been revitalized.

Phase V involves main-post housing (Area 3 and part of Area 2) and is still in the design phase. Originally scheduled to start construction in FY 1995, it may be rescheduled to FY 1996. Phases VI and VIII will involve 68 main-post housing units, while Phase VII will involve 42 off-post housing units in Area 5 (Megill Ave.). A section of the housing at Charles Woods is scheduled to be transferred to the U.S. Navy soon, so the housing makeup at Fort Monmouth will be reduced when this happens.

We found that the revitalization work in Phase IV is not addressing air-leakage and duct-leakage problems very well. Insulation is not being installed in the attics and sometimes not in the walls (even though the houses were bared to the studs). No immediate projects are scheduled to remedy the lack of attic or wall insulation. Energy efficiency has generally not been a main thrust of the revitalization work done to date at Fort Monmouth mainly because of monetary constraints.

\subsection{PHASE V AT FORT MONMOUTH}

Phase V was at about $35 \%$ of design in November 1993, when we conducted our inspection of the family housing. Table 6.3 contains a breakdown of the houses involved in this phase. Some notable energy-efficiency opportunities occur in this phase (in addition to those already mentioned) because the oil-fired hydronic heating systems are to be replaced by gas-fired, hot-air systems and central air conditioning. Currently there is no central air conditioning in this main-post housing.

No ducts currently exist in this housing because the heating systems are hydronic. This situation presents a unique opportunity to install ductwork properly with minimum leakage and to set an example of how the job should be done. Once contractors realize what their customers want and expect through proper detailed specifications (as given in the revitalization guidebook), the work will get done to everyone's satisfaction. It is also a good opportunity for the contractors to get acquainted with quality-control testing methods and to see for themselves how effective their work is.

We expect that none of the houses in this phase has wall insulation and that most of the existing heating systems are oversized. The new systems must be properly sized. They should probably not be the highest-efficiency models either (especially the air conditioners) because Fort Monmouth does not usually have particularly long or cold winters or hot summers. 
Table 6.2. Revitalization phases at Fort Monmouth

\begin{tabular}{lllcc}
\multicolumn{1}{c}{ Phase } & \multicolumn{1}{c}{ Area } & House type & Units & Year \\
\hline I, II, III & Off-post & Wherry & 365 & $1987-1990$ \\
IV & Howard Commons & Wherry & 124 & $1993-1994$ \\
V & Main-post, Area 3 & Traditional & 52 & $1995-1996$ \\
VI & Main-post, Area 2 & Traditional & 36 & - \\
VII & Off-post, Area 5 & & 42 & - \\
VIII & Main-post, Area 1 & Traditional & 32 & - \\
Summary & & & 641 & \\
\hline
\end{tabular}

aPhases I, II, and III more or less ran concurrently and involved the areas on Pine Brook, Mitchell, and Helms Avenues.

Table 6.3. Phase V revitalization project at Fort Monmouth

\begin{tabular}{cccc}
\hline $\begin{array}{c}\text { Type of } \\
\text { building }\end{array}$ & Location & $\begin{array}{c}\text { No. of } \\
\text { buildings }\end{array}$ & No. of units \\
\hline 3-BR duplex & Area 2 & 24 & 48 \\
2-BR duplex & Area 2 & 1 & 2 \\
4-BR duplex & Area 3 & 1 & 2 \\
Summary & & 26 & 52 \\
\hline
\end{tabular}

A Method 1 monitoring scheme would work well at Fort Monmouth if this phase proceeds as expected (see Table 6.4). Cooling results can be obtained for 27 units in December 1996, and both heating and cooling results for 52 units by June 1997. Any changes in starting dates for Phase $\mathrm{V}$ will change the numbers somewhat but should not significantly change the dates to obtain final results. 
Table 6.4. Method 1 monitoring of Phase $V$ at Fort Monmouth

(Construction starting October 1, 1995)

\begin{tabular}{lll}
\hline & \multicolumn{1}{c}{$\begin{array}{c}\text { July 1, 1996- } \\
\text { Sept. 30, 1996 }\end{array}$} & \multicolumn{1}{c}{$\begin{array}{c}\text { Dec. 1, 1996- } \\
\text { Sept. 30, 1997 }\end{array}$} \\
\hline Number of housing units & 27 & 25 \\
ORNL guidebook input & Yes & Yes \\
Pre-heating data & Winter '94/'95 & Winter '94/'95, '95/'96 \\
Pre-cooling data & None (no central A/C) & None (no central A/C) \\
Post-heating data & Winter '96/'97 & Winter '96/'97 \\
Post-cooling data & Summer '96 & Summer '97 \\
Heating results by & Summer '97 & Summer '97 \\
Cooling results by & Winter '96/'97 & Winter '97/'98 \\
\hline
\end{tabular}

A Method 2 approach is not proposed at this time because there are currently too many uncertainties or unknowns, such as when fuel-oil switchovers to natural gas will take place in unrevitalized houses. A Method 2 plan may be devised as we learn more about the progress of Phase V.

The opportunity for monitoring this phase almost seems made to order. Work is currently under way allowing the local municipal gas utility to install and maintain main-post gas-supply lines. The utility will also install gas meters on each house and read them on a regular basis. According to our best information, we could have access to these data. Electricmeter baseplates will be installed on the houses during revitalization, so we could install kilowatt-hour meters and have them read.

The major drawback with Phase $\mathrm{V}$ is that fuel switching will take place. Fuel-oil consumption may have to be monitored for the pre-revitalization period and gas monitored for the post-revitalization period. Monitoring the oil consumption in each house in Phase $\mathrm{V}$ would start in the fall of 1994, probably using a run-time meter to obtain pre-consumption data.

We have heard that gas bumers are being installed to replace the current fuel-oil bumers for the hydronic systems at Fort Monmouth as of March 1994, and the changeover is expected to be completed very soon. Statutory spending limits on phases often cause the dissemination of a phase into separate projects that are done before, during, and after a phase. This situation of reactionary rather than integrated planning, although necessary because of 
funding, can easily devastate a monitoring program. It is extremely difficult to effectively monitor a revitalization project and collect useful data when "energy projects" are suddenly performed in parallel with the revitalization. The effectiveness of a control group will most likely also be decimated by such actions.

If monitoring were done from October 1994 to April 1997, the following data could be obtained:

- cooling results for 27 units in December 1996, and

- $\quad$ heating results for 52 units in June 1997.

If monitoring were done from October 1994 to September 1997, the following data could be obtained:

- cooling results for 27 units in December 1996,

- cooling results for 52 units in December 1997, and

- $\quad$ heating results for 52 units in June 1997.

\subsection{RECOMMENDATIONS FOR FORT MONMOUTH}

We recommend initiating monitoring Phase V at Fort Monmouth and conducting monitoring from October 1994 through April 1997. This will allow us time to discuss the project with the A\&E firm and insert our energy guidelines into the design by June 1994.

If June 1997 is not an acceptable date for heating results, then Phase $V$ cannot be monitored, and we should abandon Fort Monmouth as a test site.

ORNL will be responsible for the following items to implement any monitoring done at Fort Monmouth:

- Ensure that the A\&E firm will use the revitalization guidebook in their design and that any recommendations are acceptable to base engineering.

- Provide any additional specifications and details to ensure that job will be done properly.

- Obtain a listing of the houses that will be revitalized, along with the best estimate of when each house will be revitalized.

- Determine which of the houses should be monitored based on the monitoring method to be used.

- Determine if fuel-oil consumption needs to be monitored and the best method of doing this.

- Obtain permission from the proper base authority to install any fuel-metering instrumentation necessary to perform monitoring. 
- Discuss with base personnel who would be an appropriate contractor to install the fuel and/or electric meters. Subcontract with either the vendor directly or with the base to install the meters and check them out.

- Purchase (or have the contractor purchase as part of the subcontract) the fuel and electric meters.

- Make arrangements with base personnel to have the meters read on a weekly basis. This may require another subcontract on our part if base personnel cannot assist us.

- Arrange to have the meter readings sent to Oak Ridge on a weekly basis.

- All meters will be left in place after monitoring is completed unless the base requests their removal. We will subcontract to have this done if necessary.

Fort Monmouth will be responsible for the following items:

- Assistance in meter installation by using their present contractor or identifying a contractor for us to use.

- Help to get the guidebook revitalization recommendations put in the revitalization design.

- Performance of weekly meter readings and sending us the data, or identifying a subcontractor for us to hire. 


\section{DETERMINATION OF SAMPLE SIZE TO OBTAIN VALID RESULTS}

One of the items that must be determined before a monitoring project can begin is the integrity of the results. The statistics associated with an experiment must be determined if the results are to be meaningful-how certain you are that results obtained from the two groups (pre- and post-revitalization for this work) are different from each other (the confidence interval), and how close the estimated difference between means actually is to the true difference. The size of the sample used and the variances of the group measurements determine these values.

Estimates of energy consumptions before and after revitalization of a group of houses at Altus AFB were used to obtain information about variability. The estimates, obtained using the Energy Economics of Design Options (EEDO) computer modeling program, measured envelope data obtained from energy audits of the houses. These estimates showed mean annual pre- and post-revitalization consumptions for space heating energy of 52 and $43 \mathrm{MBtu}$ and standard deviations of $8 \mathrm{MBtu}$ for each period (see Table 7.1).

We used a method to determine the confidence interval between two normal means with two independent samples from populations with a common variance ${ }^{2}$ to generate the data for Figs. 7.1 and 7.2. Figure 7.1 shows the relationship between sample size and the ratio of standard deviation to difference when a $95 \%$ confidence interval is desired for $B=0.1$ and $B=0.2$ (error terms, with $B=0.1$ more commonly used). A ratio of 1 was obtained from our EEDO estimates, so a sample size of 17 is required. If an allowance is made for attrition, a sample size of about 20 from each group is more correct.

Figure 7.2 extends the analysis to obtain an estimate of how close the obtained estimated difference of the means is to the true difference of the means. It shows that when a sample size of 20 with a standard deviation of 8 (our EEDO estimate) is used, we are almost $100 \%$ confident of being within $84 \%$ of the true difference of the means, $95 \%$ confident of being within $56 \%$ of the true difference of the means, but only $67 \%$ confident of being within $28 \%$ of the true difference of the means.

This brief analysis shows that a sample size of 20 housing units with pre- and postrevitalization data is probably the minimum that we want to use in a monitoring project to obtain acceptable estimates of any savings caused by the revitalization process. 
Table 7.1. EEDO estimates of heating energy savings from houses at Altus AFB

\begin{tabular}{|c|c|c|c|c|}
\hline \multirow[b]{2}{*}{ House } & \multirow[b]{2}{*}{ Area $\left(\mathrm{ft}^{2}\right)$} & \multicolumn{3}{|c|}{$\begin{array}{c}\text { EEDO }{ }^{\alpha} \text { estimated space-heating energy } \\
\text { (MBtu/year) }\end{array}$} \\
\hline & & Pre-period & Post-period & Savings \\
\hline 01 & 903 & 41.7 & 30.4 & 11.3 \\
\hline 02 & 1369 & 47.9 & 40.9 & 7.0 \\
\hline 03 & 1176 & 50.1 & 40.4 & 9.7 \\
\hline 04 & 1219 & 46.3 & 36.2 & 10.1 \\
\hline 05 & 1601 & 64.4 & 54.9 & 9.5 \\
\hline 06 & 1385 & 59.6 & 50.3 & 9.3 \\
\hline 07 & 1250 & 51.4 & 45.8 & 5.6 \\
\hline Mean & 1272 & 51.6 & 42.7 & 8.9 \\
\hline St. Dev. & 216 & 7.9 & 8.3 & 2.0 \\
\hline
\end{tabular}

EEDO = Energy Economics of Design Options (Computer modeling program).

'Standard deviation. 




Fig. 7.1. Sample size necessary to detect a difference between two groups with $95 \%$ confidence.

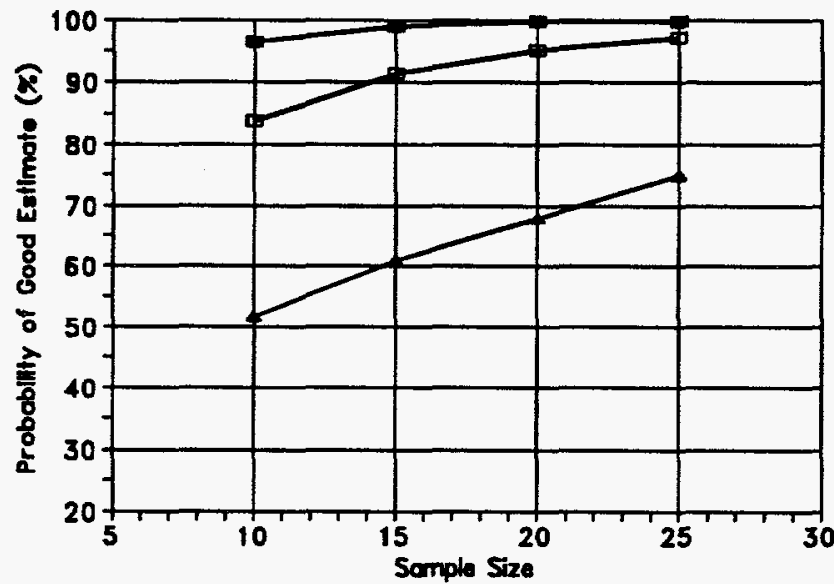

trin $28 \%$

$\rightarrow$

within $56 \%$

$\rightarrow-$

within $84 \pi$

Fig. 7.2. Probability of an estimate's accuracy when the standard deviation is 8 . 


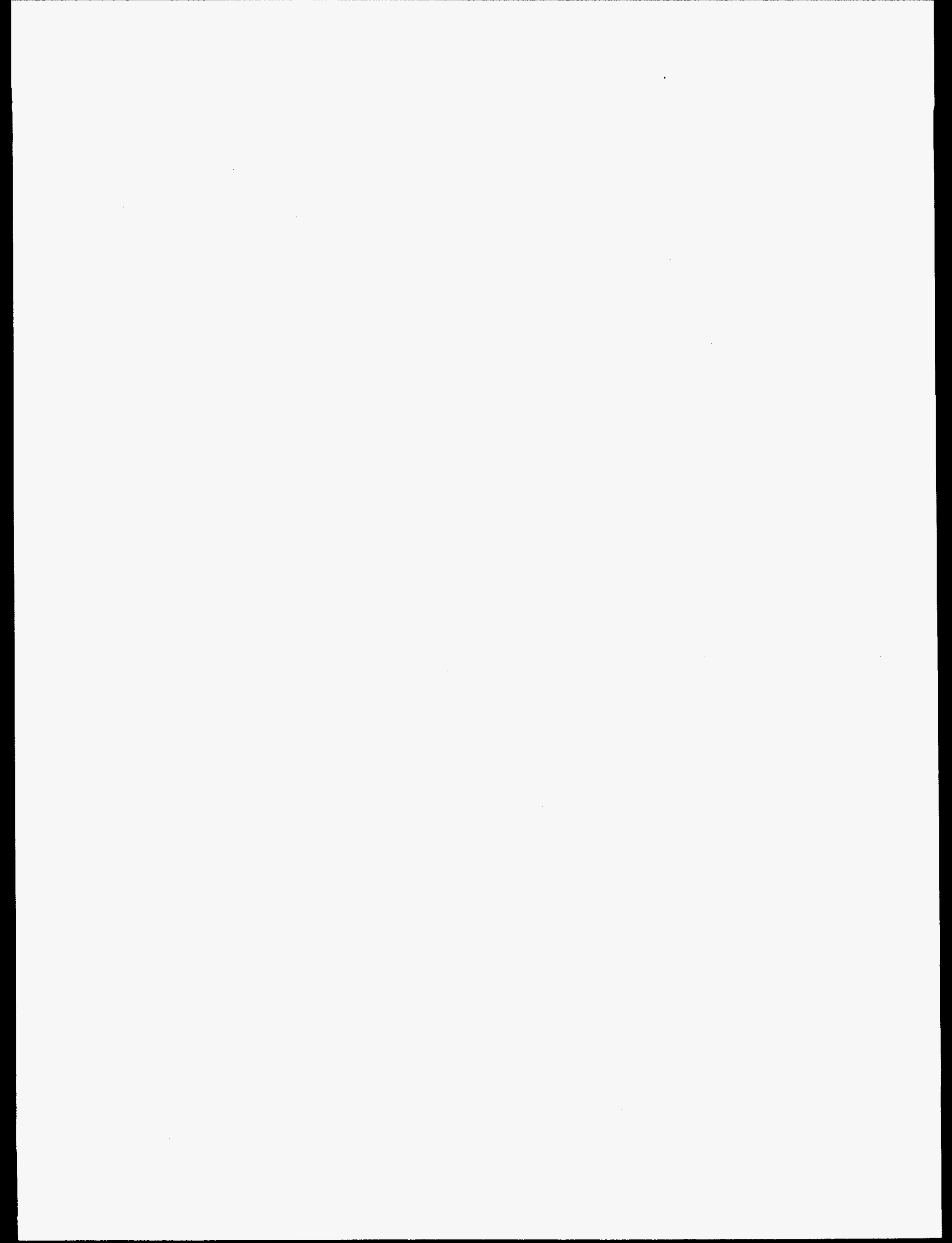




\section{RECOMMENDATIONS}

- We do not recommend conducting monitoring at Malmstrom AFB unless the high probability of measuring little or no savings is acceptable.

- We recommend initiating monitoring at Altus AFB and at Fort Monmouth by

- getting the revitalization design guidebook recommendations into the revitalization designs at each installation,

- installing electric meters by June and gas meters by November 1994 at Altus AFB, and

- installing the proper heating fuel meters (oil or gas) at Fort Monmouth by November 1994.

- We do not recommend seeking out other installations to monitor because

- two installations are sufficient to obtain a good start;

- revitalization schedules at other installations are not likely to be any more attractive than for those installations we inspected; and

- it takes a significant amount of front-end time to ascertain existing conditions, determine the feasibility of conducting monitoring, and estimate the expected savings at an installation. 


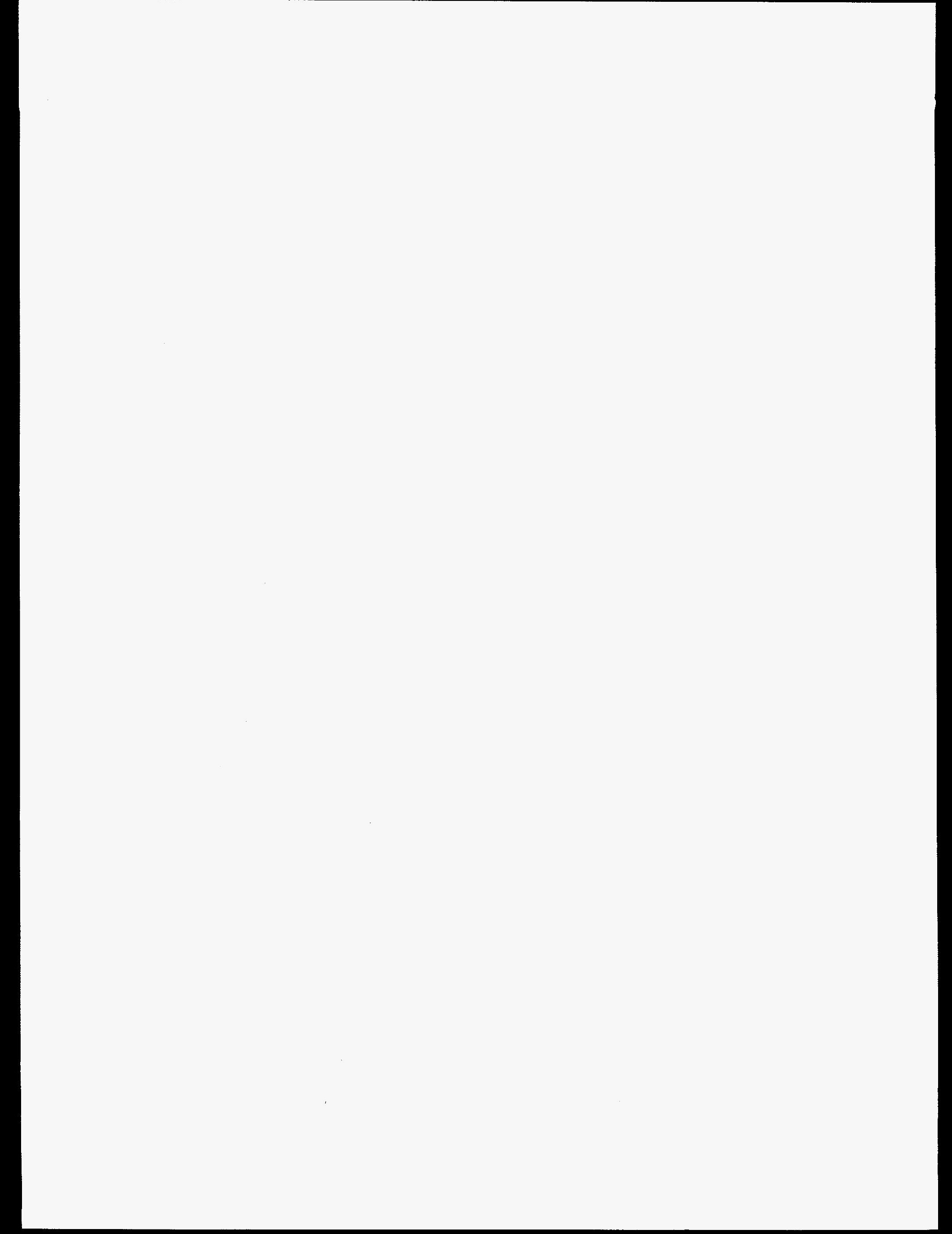




\section{REFERENCES}

1. Engineering Weather Data, AFM 88-29, July 1978.

2. A. E. Mace, Sample Size Determination, Reinhold Publishing Corp., New York, 1964. 
APPENDIX 
Table A.1. Proposed military family housing total energy use budget for new construction

\begin{tabular}{|c|c|c|c|c|}
\hline \multirow[b]{2}{*}{ Region } & \multirow{2}{*}{$\begin{array}{l}\text { Cooling } \\
\text { degree } \\
\text { days }\end{array}$} & \multicolumn{2}{|c|}{ Heating degree days } & \multirow{2}{*}{$\begin{array}{c}\text { DOD Energy Use } \\
\text { Budget } \\
\text { [MBtu/(kSF } \cdot \text { yr })]\end{array}$} \\
\hline & & Minimum & Maximum & \\
\hline 1 & - & 15,000 & - & 70 \\
\hline 2 & 一 & 13,000 & 15,000 & 65 \\
\hline 3 & 一 & 11,000 & 13,000 & 60 \\
\hline 4 & $<2,000$ & 9,000 & 11,000 & 55 \\
\hline 5 & $<2,000$ & 7,000 & 9,000 & 55 \\
\hline 6 & $<2,000$ & 5,500 & 7,000 & 45 \\
\hline 7 & $<2,000$ & 4,000 & 5,500 & 45 \\
\hline 8 & $<2,000$ & 2,000 & 4,000 & 45 \\
\hline 9 & $<2,000$ & - & 2,000 & 40 \\
\hline 10 & $>2,000$ & - & 2,000 & 50 \\
\hline 11 & $>2,000$ & $>2,000$ & - & 55 \\
\hline
\end{tabular}

Proposed by U.S. Department of Defense for new construction and revised in September 1992. 
Table A. DEIS energy use data for potential military base monitoring sites

\begin{tabular}{|c|c|c|c|c|c|c|c|}
\hline \multirow[b]{2}{*}{ Military base } & \multicolumn{4}{|c|}{ AFM 88-29 data } & \multirow{2}{*}{\multicolumn{2}{|c|}{$\begin{array}{l}\text { No. of } \\
\text { MFH } \\
\text { bldgs. }\end{array}$}} & \multirow{2}{*}{$\begin{array}{l}\text { Area } \\
(\mathrm{kSF})\end{array}$} \\
\hline & \multicolumn{2}{|c|}{ Heating DD } & \multicolumn{2}{|c|}{ Cooling DD } & & & \\
\hline Malmstrom, Mont. & \multicolumn{2}{|c|}{7671} & \multicolumn{2}{|c|}{370} & \multicolumn{2}{|c|}{544} & 2115 \\
\hline Altus AFB, Okla. & \multicolumn{2}{|c|}{3346} & \multicolumn{2}{|c|}{2347} & \multicolumn{2}{|c|}{715} & 1110 \\
\hline Aberdeen PG, Md. & \multicolumn{2}{|l|}{5184} & \multicolumn{2}{|c|}{1076} & \multicolumn{2}{|c|}{400} & 1876 \\
\hline \multirow[t]{3}{*}{ Ft. Monmouth, N.J. } & \multicolumn{2}{|c|}{5128} & \multicolumn{2}{|c|}{770} & \multicolumn{2}{|c|}{228} & 1646 \\
\hline & \multicolumn{6}{|c|}{$\begin{array}{l}\text { DEIS-reported MFH energy usage } \\
{[\mathrm{MBtu} /(\mathrm{kSF} \cdot \mathrm{yr})]}\end{array}$} & DOD \\
\hline & $\begin{array}{l}\text { Total } \\
1985\end{array}$ & $\begin{array}{l}\text { Total } \\
1992\end{array}$ & $\begin{array}{l}\text { Heat } \\
1985\end{array}$ & $\begin{array}{l}\text { Heat } \\
1992\end{array}$ & $\begin{array}{l}\text { Elec. } \\
1985\end{array}$ & $\begin{array}{l}\text { Elec. } \\
1992\end{array}$ & $\begin{array}{c}\text { use } \\
\text { budget }\end{array}$ \\
\hline Malmstrom, Mont. & 143.2 & 98.5 & 120.5 & 73.9 & 22.7 & 24.6 & 55 \\
\hline Altus AFB, Okla. & 120.4 & 99.0 & 77.8 & 64.3 & 42.7 & 34.7 & 55 \\
\hline Aberdeen PG, Md. & 117.5 & 81.3 & 96.4 & 40.9 & 21.2 & 40.4 & 45 \\
\hline Ft. Monmouth, N.J. & 121.9 & 151.5 & 98.7 & 129.0 & 23.2 & 22.5 & 45 \\
\hline
\end{tabular}

Note $: \mathrm{DD}=$ degree day; $\mathrm{MFH}=$ military family housing. 
ORNL/TM-12723

\section{INTERNAL DISTRIBUTION}

\author{
1-50. W. P. Levins \\ 51-52. M. P. Ternes \\ 53. M. M. Abraham \\ 54. J. B. Cannon \\ 55. J. E. Christian \\ 56. G. E. Courville \\ 57. P. D. Fairchild \\ 58. M. B. Gettings \\ 59. J. M. MacDonald \\ 60. H. A. McLain \\ 61-63. R. R. Parks
}

64. A. C. Schaffhauser

65. T. R. Sharp

66. R. B. Shelton

67. R. L. Wendt

68. K. E. Wilkes

69. P. Wolff

70-71. Central Research Library

72. Document Reference Section

73-75. Laboratory Records

76. Laboratory Records-RC

77. ORNL Patent Office

\section{EXTERNAL DISTRIBUTION}

78. T. Adams, HQ AFCESA/EN, 139 Bames Drive, Suite 1, Tyndall AFB, FL 32403-5319

79. R. Baker, HQ AF CESA/EN, 139 Barnes Drive, Suite 1, Tyndall AFB, FL 32403-5319

80. F. Beason, HQ AFCESA/EN, 139 Barnes Drive, Suite 1, Tyndall AFB, FL 32403-5319

81. Dr. Douglas R. Bohi, Director, Energy and Natural Resources Division, Resources for the Future, 1616 P Street, N.W., Washington DC 20036

82. R. Castellanos, U.S. Air Force, Housing Technical Branch, HQ USAF/LEEHT, Pentagon, Room 5D-440, Washington, D.C. 20330-5140

83. J. W. Cooke, DOE, Field Office, Post Office Box 2008, Oak Ridge, TN 37831-6269

84. L. Davis, 97 CES/CEC, 41 L Avenue, Building 357, Altus AFB, OK 75323-5138

85. Dr. T. E. Drabek, Professor, Department of Sociology, University of Denver, Denver, CO 80208-0209

86. C. Fields, 97 CES/CEC 41 L Avenue, Building 357, Altus AFB, OK 7523-5138

87. G. Fitzmaier, Directorate of Public Works, ATTN: SELFM-TW-EP, Building 167, Fort Monmouth, NJ 07703-5108

88. M. Ginsberg, Office of Federal Energy Management Program, EE-44, 5E-080/Forrestal Building, 1000 Independence Avenue, Washington, D.C. 20585

89. P. Goutos, Chief Army Housing Facilities Division, U.S. Army Engineering \& Housing Support Center (CEHSC-HF), Room 102 Casey Building, Fort Belvoir, VA 22060-5516

90. M. M. Herbert, Directorate of Engineering and Housing, Building 270/ATTN: SELF-EH-H, Fort Monmouth, NJ 07703-5109

91. Dr. Stephen G. Hildebrand, Director, Environmental Sciences Division, Oak Ridge National Laboratory, P. O. Box 2008, Oak Ridge, Tennessee 37831-6037

92. A. Houtzager, Army Housing Facilities Division, U.S. Army Engineering \& Housing Support Center (CEHSC-HF), Room 102 Casey Building, Fort Belvoir, VA 22060-5516

93. G. James, USAF, HQ AETC/CEPH, 266 F. St. West, Randolph AFB, TX 78150-4321

94. R. N. Karney, Department of Energy, EE-421, 5E-098/FORS, 1000 Independence Avenue, S.W., Washington, D.C. 20585 
95. T. Ketchum, Army Housing Facilities Division, U.S. Army Engineering \& Housing Support Center (CEHSC-HF), Room 102 Casey Building, Fort Belvoir, VA 22060-5516

96. L. Layton, Army Housing Facilities Division, U.S. Army Engineering \& Housing Support Center (CEHSC-HF), Room 102 Casey Building, Fort Belvoir, VA 22060-5516

97. Mr. Calvin D. MacCraken, President, Calmac Manufacturing Corporation, P.O. Box 710, Englewood, NJ 07631

98. J. McCarty, Army Housing Facilities Division, U.S. Army Engineering \& Housing Support Center (CEHSC-HF), Room 102 Casey Building, Fort Belvoir, VA 22060-5516

99. 1st Lt. M. Mongold, 97 CES/CEOE, 501 L Avenue, Building 362, Altus AFB, OK 75323

100. R. Moretti, Deputy of Civil Engineering, 43 CES/CECR, Building 470, Malmstrom AFB, MT 59402

101. R. Nader, Post Office Box 19367, Washington, D.C. 20036

102. J. Ott, Directorate of Public Works, Building 167, ATTN: SELSM-PW, Fort Monmouth, NJ 07703-5000

103. S. Scully, NAHB Research Center, 400 Prince George Blvd., Upper Marlboro, MD 20772

104. J. B. Shrago, Director, Office of Technology Transfer, 405 Kirkland Hall, Vanderbilt University, Nashville, TN 37240

105. G. F. Sowers, P.E., Senior Vice President, Law Companies Group, Inc., 114 Townpark Drive, Suite 250, Kennesaw, GA 30144-5599

106. C. M. Walton, Department of Civil Engineering, College of Engineering, The University of Texas, Cockrell Hall, Suite 4.2, Austin, TX 78712

107. G. Willems, Assistant for Family Housing and Facility Maintenance, Deputy Assistant Secretary for Installations, SAF/RI, Pentagon, Suite 4C940, Washington, D.C. 20330-1000

108. Office of Assistant Manager for Energy Research and Development, DOE Oak Ridge Field Office, P.O. Box 2008, Oak Ridge, TN 37831-6269

109-110. OSTI, U.S. Department of Energy, P. O. Box 62, Oak Ridge, TN 37831 